\title{
25. CHEMICAL AND MINERALOGICAL STUDIES, SITES 322 AND 325
}

\author{
Edward A. Perry, Jr., Edward C. Beckles, and Robert M. Newton, \\ Department of Geology, University of Massachusetts, Amherst, Massachusetts
}

\section{INTRODUCTION}

The results in this report represent part of a combined geochemical research program into the diagenesis and geochemical evolution of deep-sea sediments. Other workers have determined pore water chemistry (Gieskes, this volume) and isotopic compositions (Anderson and Lawrence and Lawrence et al., both this volume), and our complementary studies detail the sediment mineralogy and chemistry at Site 322, the sediment mineralogy at Site 325 , and the alteration products of the basal basalts encountered at Site 322 .

\section{EXPERIMENTAL METHODS}

The sediment samples were repeatedly washed in distilled water until flocculation no longer occurred and then separated into the $\langle 1 \mu \mathrm{m}$ and $>1 \mu \mathrm{m}$ fraction by centrifugal sedimentation. The $>1 \mu \mathrm{m}$ fraction was dried, gently ground in acetone, and analyzed on a glass slide by X-ray diffraction (XRD). Oriented XRD specimens of the $<1 \mu \mathrm{m}$ fractions were prepared by allowing a distilled water suspension to dry on a glass slide at room temperature.

The determination of clay mineral abundances by XRD is notoriously unreliable because of variations in chemical composition, particle size, "crystallinity," and sample preparation effects such as orientation (see also Towe, 1974). We have, therefore, presented our clay mineral data only in terms of the relative XRD peak intensity. The strongest XRD peaks were chosen in order to minimize the effects of differing degrees of preferred orientation which most strongly modify the intensity of the weaker, higher order XRD peaks. The $10 \AA$ peak is measured for illite (a discrete mica phase), and the $7 \AA$ peak is used for chlorite, as kaolinite was found to be absent or present only in trace amounts. The $17 \AA$ peak was chosen for mixed-layer=illite/smectite (hereafter referred to simply as illite/smectite), but its peak intensity varies as a function of the proportion of smectite layers relative to illite layers (Reynolds and Hower, 1970). We, therefore, also report the proportion of smectite layers in the illite/smectite as determined by the methods of Reynolds and Hower (1970).

Chemical analyses of the washed $\langle 1 \mu \mathrm{m}$ and $>1 \mu \mathrm{m}$ fractions were performed by automated electron microprobe analysis. Loss on ignition was determined at $950^{\circ} \mathrm{C}$ and the ignited sample was fused with a $1: 1 \mathrm{mix}-$ ture of $\mathrm{Li}_{2} \mathrm{~B}_{4} \mathrm{O}_{7}$. Six analyses (with matrix corrections) were performed on each of the resulting fused glasses and the mean of the six analyses for each sample is reported in Tables 1 and 2.

In Core 11 of Site 322, several closely spaced samples were analyzed. For the purposes of plotting our mineralogic and chemical data in the figures of this text, we have averaged three sets of data and plotted each as a single point. The three sets of data averaged are indicated by brackets in Tables 1 and 2, and it can be seen that no major chemical differences exist within each set of averaged data.

\section{SITE 322 RESULTS}

\section{Mineralogy}

The upper 295 meters of the sediments sampled appear to be dominantly terrigenous in origin. The coarse fraction has abundant quartz, feldspar, and hornblende. The clay mineralogy consists of illite, chlorite, and illite/smectite (Figure 1). Kaolinite is absent or present only in trace amounts. The illite/smectite is somewhat heterogeneous in its proportion of smectite layers, but consistently averages about $60 \%$ smectite layers in the upper 295 meters. The major proportion of these clays appear to be detrital in origin. This sediment section corresponds to lithologic Unit 1 and has been described as a mature, unconsolidated mixture of sand, silt, and clay of late Miocene to early Pliocene age (Site 322 report, this volume).

Two samples (4-2 and 5-1) were examined from the underlying Unit 2 which has been described as an immature claystone of probable late Miocene age. The samples were taken at 355 and 392 meters and have the same detrital illite, chlorite, and illite/smectites (60\% expandable) as Unit 1 . However, clinoptilolite is now present in both the coarse and fine fractions even though the clay mineralogy does not seem to indicate any abundant alteration of volcanics. The clinoptilolite may have precipitated from the pore waters, perhaps incorporating ions which have diffused upwards from the more volcanic-rich sediments below.

Section 6-1 $(438 \mathrm{~m})$ is the first sample encountered that has a drastically different clay mineralogy from the overlying sediments. Clinoptilolite is still present, but illite and chlorite are now present in minor amounts (Figure 1). Also, the illite/smectite is now essentially a pure smectite with nearly $100 \%$ smectite layers. As can be deduced from arguments detailed elsewhere (Perry et al., in press), this mineralogy represents the submarine alteration of volcanics. This first evidence of volcanic alteration coincides with the highest $\mathrm{SiO}_{2}$ pore water value of Gieskes and Lawrence (this volume). The clay mineralogy is dominated by nearly pure smectites to a depth slightly greater than 512 meters, although clinoptilolite only persists in any abundance to a depth of 509 meters. This section of sediments from 438 to 512 meters must be very enriched in altered volcanics, although detrital minerals are still found in the coarse fraction of the sediments.

The basal 2 meters of sediment are not as enriched in volcanics. The clays have more abundant detrital illite and chlorite, and the illite/smectite now has only $60 \%$ 
TABLE 1

\begin{tabular}{llllllllllr}
\hline $\begin{array}{c}\text { Sample } \\
\text { (Interval } \\
\text { in cm) }\end{array}$ & $\begin{array}{c}\text { Approx. } \\
\text { Depth } \\
(\mathrm{m})\end{array}$ & $\mathrm{K}_{2} \mathrm{O}$ & $\mathrm{CaO}$ & $\mathrm{TiO}_{2}$ & $\mathrm{Na}_{2} \mathrm{O}$ & $\mathrm{MgO}$ & $\mathrm{Al}_{2} \mathrm{O}_{3}$ & $\mathrm{SiO}_{2}$ & $\mathrm{MnO}_{2}$ & $\mathrm{Fe}_{2} \mathrm{O}_{3}{ }^{\mathrm{a}}$ \\
\hline $1-1,0-15$ & 76.5 & 2.07 & 0.45 & 0.86 & 1.26 & 5.04 & 14.27 & 66.23 & 0.38 & 9.44 \\
$1-2,135-140$ & 79.5 & 1.76 & 0.32 & 0.82 & 1.08 & 3.64 & 12.13 & 72.07 & 0.17 & 8.03 \\
$2-2,103-107$ & 193 & 1.91 & 0.32 & 0.82 & 1.13 & 3.85 & 12.61 & 71.40 & 0.09 & 7.88 \\
$3-1,0-12$ & 295 & 2.67 & 0.54 & 0.93 & 1.27 & 4.86 & 15.55 & 63.02 & 0.29 & 10.85 \\
$4-2,135-150$ & 355 & 2.32 & 0.70 & 1.10 & 1.38 & 4.59 & 16.09 & 63.46 & 0.28 & 10.08 \\
$5-1,72-76$ & 391.5 & 2.72 & 0.39 & 1.17 & 1.10 & 4.58 & 17.19 & 63.01 & 0.15 & 9.69 \\
$6-1,18-22$ & 438.5 & 3.09 & 0.39 & 0.84 & 1.32 & 3.45 & 17.18 & 62.39 & 1.38 & 9.96 \\
$10-0,0-15$ & 486 & 2.78 & 0.61 & 1.26 & 1.32 & 5.53 & 17.16 & 59.98 & 0.37 & 11.02 \\
$11-1,148-150$ & 505.5 & 0.99 & 0.24 & 1.39 & 0.83 & 10.45 & 14.03 & 62.21 & 0.35 & 9.52 \\
$11-2,125-127$ & 506.5 & 1.10 & 0.15 & 1.82 & 0.74 & 10.48 & 14.00 & 60.68 & 0.35 & 10.23 \\
$11-3,125-128$ & 508 & 1.18 & 0.05 & 1.83 & 0.90 & 10.16 & 14.15 & 60.24 & 0.37 & 11.12 \\
$11-4,40-43$ & 509 & 2.62 & 0.57 & 1.99 & 1.27 & 4.98 & 17.81 & 63.16 & 0.55 & 7.06 \\
$11-4,62-64$ & 509.5 & 4.07 & n.d. & 0.80 & 0.86 & 4.31 & 16.83 & 62.60 & 0.39 & 10.13 \\
$11-4,122-124$ & 509.8 & 2.63 & n.d. & 0.87 & 0.89 & 4.10 & 16.36 & 63.07 & 0.64 & 11.44 \\
$11-5,18-20$ & 510 & 2.95 & 0.15 & 0.98 & 1.09 & 4.23 & 16.60 & 62.11 & 0.71 & 11.17 \\
$11-5,110-112$ & 510.5 & 4.21 & n.d. & 0.90 & 1.16 & 3.37 & 17.92 & 59.86 & 0.85 & 11.74 \\
$11-6,30-32$ & 512 & 4.25 & n.d. & 0.77 & 0.98 & 3.58 & 19.37 & 59.20 & 1.75 & 10.14 \\
$11-6,103-105$ & 512.5 & 4.21 & n.d. & 0.78 & 0.95 & 3.35 & 18.60 & 58.53 & 1.68 & 11.88 \\
$11, \mathrm{CC}$ & 513.8 & 4.41 & n.d. & 0.71 & 0.81 & 3.71 & 19.31 & 58.28 & 1.71 & 11.09 \\
$11, \mathrm{CC}$ & 513.9 & 4.45 & n.d. & 0.75 & 0.89 & 3.27 & 19.17 & 57.62 & 1.65 & 12.19 \\
$11, \mathrm{CC}$ & 514 & 3.96 & n.d. & 0.78 & 0.77 & 3.72 & 19.10 & 58.63 & 1.79 & 11.25 \\
\hline
\end{tabular}

Note: Brackets indicate closely spaced samples which have been averaged together for graphical purposes in Figures 3 and 4.

${ }^{\mathrm{a}}$ Total iron as $\mathrm{Fe}_{2} \mathrm{O}_{3}$.

$\mathrm{b}_{\text {n.d. }}=$ not detected.

TABLE 2

$\left.\begin{array}{lllllllllll}\hline \begin{array}{c}\text { Sample } \\ \text { (Interval } \\ \text { in cm) }\end{array} & \begin{array}{c}\text { Approx. } \\ \text { Depth } \\ (\mathrm{m})\end{array} & \mathrm{K}_{2} \mathrm{O} & \mathrm{CaO} & \mathrm{TiO}_{2} & \mathrm{Na}_{2} \mathrm{O} & \mathrm{MgO} & \mathrm{Al}_{2} \mathrm{O}_{3} & \mathrm{SiO}_{2} & \mathrm{MnO}_{2} & \mathrm{Fe}_{2} \mathrm{O}_{3} \mathrm{a}^{\mathrm{a}} \\ \hline 1-1,0-15 & 76.5 & 1.71 & 2.68 & 0.76 & 2.97 & 2.28 & 14.62 & 70.08 & 0.09 & 4.79 \\ 1-2,135-140 & 79.5 & 1.57 & 3.16 & 0.75 & 2.81 & 2.28 & 13.41 & 72.21 & 0.07 & 3.52 \\ 2-2,103-107 & 193 & 1.61 & 3.37 & 0.71 & 3.34 & 1.91 & 14.58 & 70.60 & 0.08 & 3.81 \\ 3-1,0-12 & 295 & 1.87 & 3.63 & 0.81 & 3.01 & 2.76 & 15.68 & 66.73 & 0.13 & 5.40 \\ 4-2,135-150 & 355 & 1.66 & 4.65 & 0.71 & 3.69 & 2.01 & 16.41 & 66.02 & 0.13 & 4.72 \\ 5-1,72-76 & 391.5 & 2.02 & 3.91 & 0.84 & 3.75 & 1.74 & 16.95 & 66.28 & 0.24 & 4.27 \\ 6-1,18-22 & 438.5 & 2.65 & 2.89 & 0.80 & 3.20 & 1.42 & 16.14 & 69.50 & 0.26 & 3.14 \\ 10-0,0-15 & 486 & 2.01 & 3.00 & 0.73 & 3.27 & 1.62 & 16.54 & 67.53 & 0.39 & 4.93 \\ 11-1,148-150 & 505.5 & 1.53 & 3.73 & 0.67 & 3.79 & 2.20 & 15.54 & 68.71 & 0.26 & 3.57 \\ 11-2,125-127 & 506.5 & 1.63 & 3.40 & 0.67 & 3.98 & 2.30 & 15.10 & 68.96 & 0.05 & 3.90 \\ 11-3,125-128 & 508 & 1.63 & 3.15 & 0.74 & 3.64 & 1.86 & 14.86 & 70.06 & 0.42 & 3.64 \\ 11-4,40-43 & 509 & 2.03 & 3.24 & 0.92 & 3.96 & 1.49 & 17.34 & 66.32 & 0.43 & 4.26 \\ 11-4,62-64 & 509.5 & 3.63 & 0.59 & 0.88 & 1.93 & 3.12 & 15.74 & 67.52 & 0.44 & 6.17 \\ 11-4,122-124 & 509.8 & 3.13 & 1.06 & 0.98 & 1.87 & 2.90 & 16.39 & 65.80 & 0.19 & 7.67 \\ 11-5,18-20 & 510 & 3.38 & 2.12 & 1.08 & 2.85 & 3.10 & 17.36 & 64.02 & 0.39 & 5.70 \\ 11-5,110-112 & 510.5 & 3.58 & 1.01 & 0.88 & 2.26 & 2.17 & 16.05 & 66.93 & 1.17 & 5.94 \\ 11-6,30-32 & 512 & 4.72 & 0.62 & 0.87 & 1.92 & 2.20 & 16.33 & 67.14 & 0.87 & 5.32 \\ 11-6,103-105 & 512.5 & 4.77 & 0.53 & 0.79 & 2.00 & 1.75 & 15.32 & 69.09 & 0.46 & 5.29 \\ 11, \mathrm{CC} & 513.8 & 4.77 & 0.52 & 0.75 & 1.84 & 2.14 & 15.86 & 67.61 & 1.23 & 5.29 \\ 11, \mathrm{CC} & 513.9 & 4.47 & 0.70 & 0.74 & 2.00 & 2.52 & 16.39 & 64.70 & 1.37 & 7.10 \\ 11, \mathrm{CC} & 514 & 4.49 & 1.06 & 0.72 & 2.00 & 1.89 & 15.42 & 67.89 & 1.16 & 5.34\end{array}\right\}$

Note: Brackets indicate closely spaced samples which have been averaged together for graphical purposes in Figures 3 and 4.

${ }^{\mathrm{a}} \mathrm{Total}$ iron as $\mathrm{Fe}_{2} \mathrm{O}_{3}$.

smectite layers as opposed to being a nearly pure smectite. These lowermost sediments have much more of a detrital component than the altered volcanic claystones above them.

In addition to the sediment samples, four volcanic drilling breccias were also examined by XRD to deter- mine the mineralogy of the alteration products. Sample $12-1,90-100 \mathrm{~cm}$ has clay pebbles mixed with a basalt breccia. The clay is mainly authigenic smectite plus clinoptilolite, but does have minor amounts of detrital illite and chlorite. Sample 12-1, 130-140 cm is a volcanic breccia which is altering to smectite and phillipsite; the 


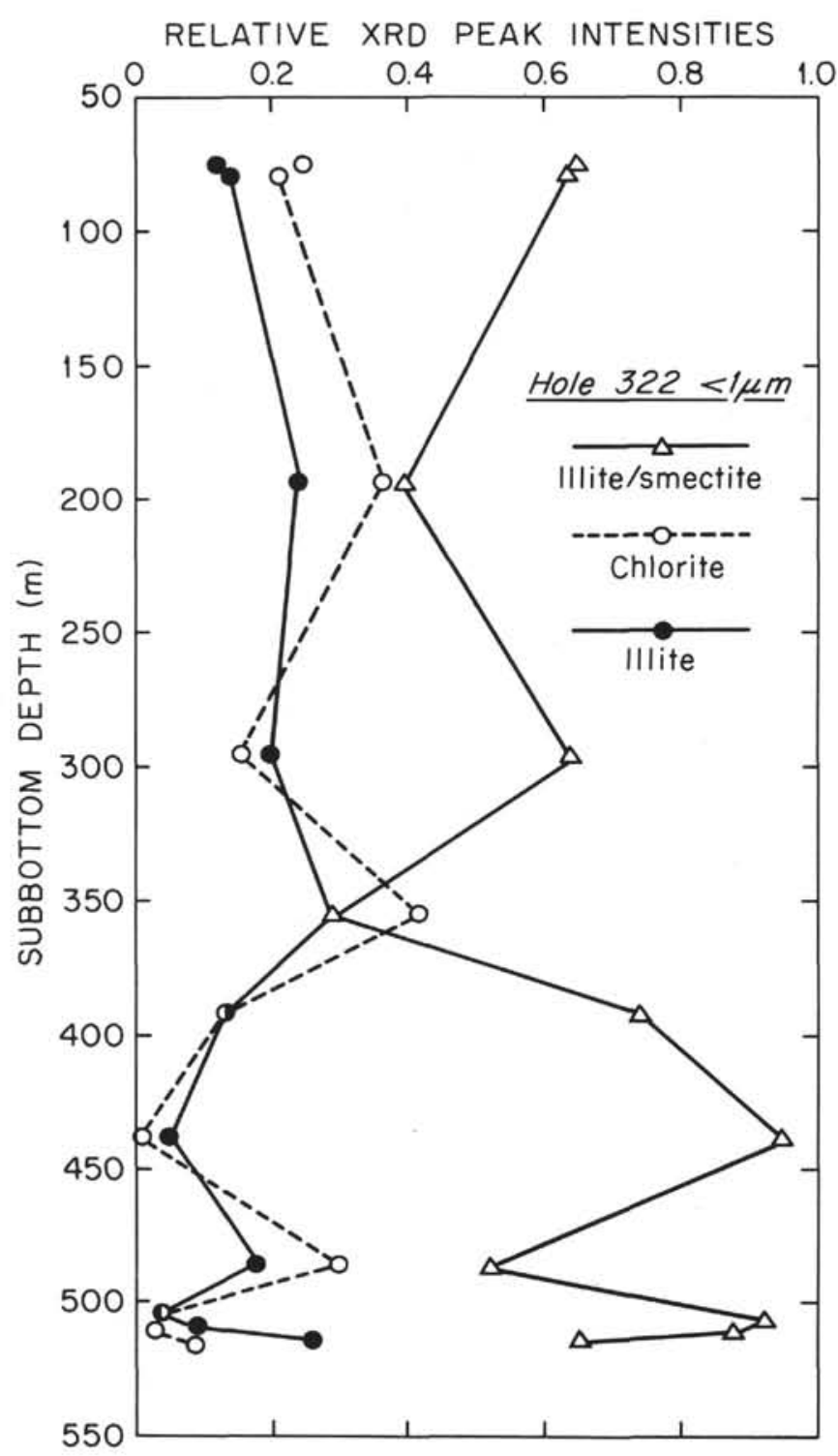

Figure 1. Relative XRD peak intensity of the clay minerals in the $<1 \mu \mathrm{m}$ fractions of sediments from Site 322 plotted against sample subbottom depth. The intensity of a given XRD peak is normalized to the total intensity of the 7,10 , and $17 \AA X R D$ peaks.

same is true of Sample 13-1, 25-26 cm. Sample 13-1, 130 $\mathrm{cm}$ is composed of a mixture of hard volcanic pebbles and soft pebbles. The clays found are authigenic smectite, clinoptilolite, and detrital illite plus chlorite. The soft pebbles are apparently a mixture of volcanic alteration products and detrital sediments. With the exception of phillipsite, all the basalt fragments appear to be altering to the same smectite plus minor clinoptilolite mineralogy as found in the overlying sediments.

\section{Sediment Chemistry}

Tables 1 and 2 give the major element chemistry of the washed, ignited $<1 \mu \mathrm{m}$ and $>1 \mu \mathrm{m}$ sediment fractions. $\mathrm{Ca}, \mathrm{Na}$, and $\mathrm{Si}$ are much more abundant in the coarse fraction as its mineralogy is dominated by quartz plus plagioclase. $\mathrm{Mg}$ is much more abundant in the fine fraction due to its presence in both chlorite and illite/smec- tite. Illite (K-mica) is present in both size fractions and there is $\mathrm{K}$-feldspar in the coarse fraction so that $\mathrm{K}$ does not exhibit any consistent differences in abundance between the coarse and fine fractions.

\section{SITE 325 RESULTS}

Only mineralogy has been determined for the sediments of Site 325. Two sedimentary units are recognized with the boundary between the two occurring at about 570 meters (Site 325 report). The upper 570 meters of sediments are a mixture of silty clay, silty claystone, and claystone ranging in age from Miocene to Quaternary. The coarse fraction is dominated by quartz and plagioclase, and the fine fraction has a clay mineral suite of illite, chlorite, and illite/smectite (Figure 2). The illite/smectite is similar to that found in the upper part of Site 322 and also has an average of about $60 \%$ smectite layers.

The lower sediment unit (early Miocene) is richer in sandstones and siltstones than the upper unit, but the clay mineralogy of two claystones $(642$ and $710 \mathrm{~m})$ from this unit indicates altered volcanics. Some clinoptilolite is found from 615 to 622 meters and again could have precipitated from pore waters and incorporated ions

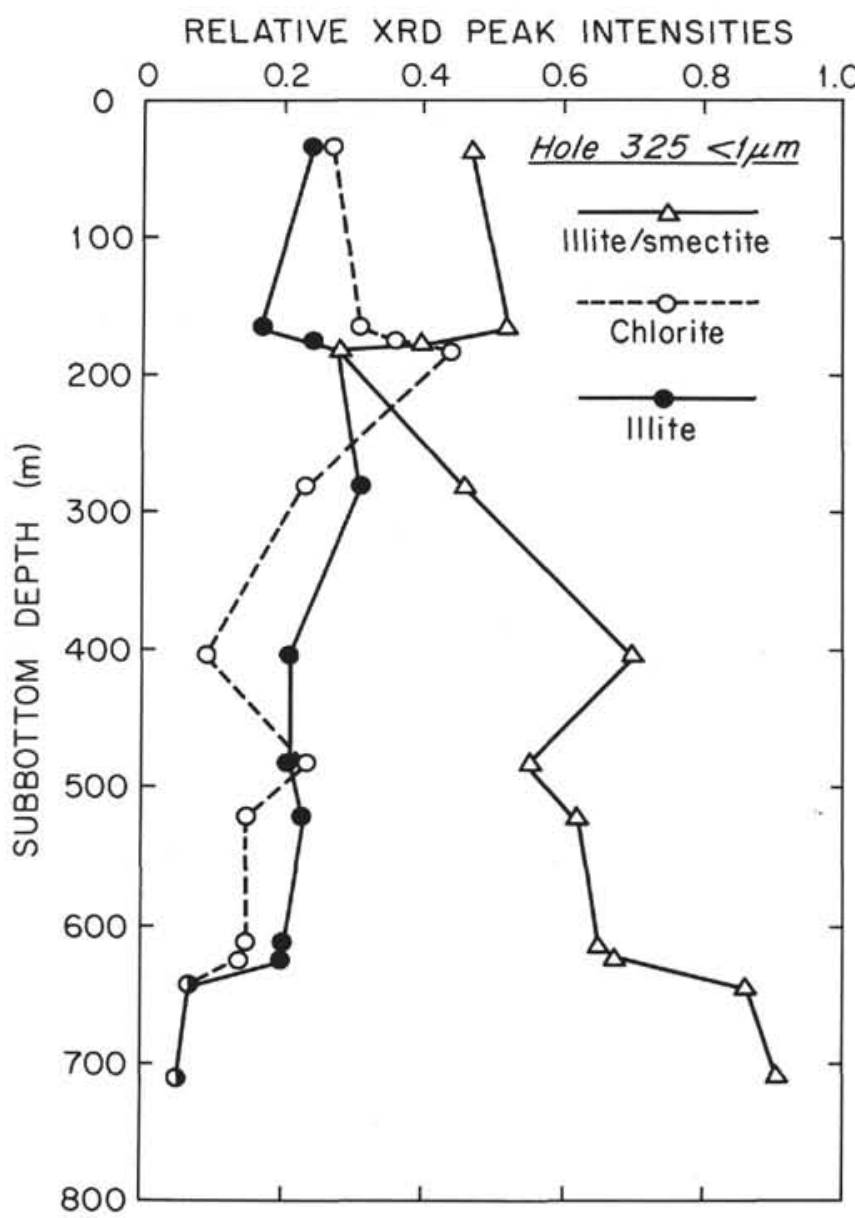

Figure 2. Relative XRD peak intensity of the clay minerals in the $<1 \mu \mathrm{m}$ fraction of sediments from Site 325 plotted against sample subbottom depth. The intensity of a given $X R D$ peak is normalized to the total intensity of the 7, 10 , and $17 \AA X R D$ peaks. 
which may have diffused upward from these volcanics. Detrital illite and chlorite are less abundant (Figure 2), and the clays are dominated by illite/smectite with nearly $100 \%$ smectite layers. Clinoptilolite is also present.

\section{DISCUSSION}

The above mineralogic and chemical data can at least partially explain some of the pore water chemical gradients found by Gieskes and Lawrence (this volume). At Site 322, the following pore water trends were observed with increasing core depth: (1) a depletion in dissolved $\mathrm{Mg}$, (2) an enrichment in $\mathrm{Ca}$ which is larger than the $\mathrm{Mg}$ depletion, and (3) a depletion in $\mathrm{K}$. The pore waters also exhibit a depletion in $\mathrm{O}^{18}$ (Lawrence et al., this volume).

Our chemical data on the fine and coarse fractions (Figures 3 and 4 ) do not seem to indicate any major chemical or mineralogical changes in the upper 400 meters of detrital sediments. Illite and chlorite covary closely in abundance which would imply a common provenance, while the illite/smectite exhibits a larger variation in its abundance (Figure 1). The illite/smectite of upper sediment section is somewhat heterogeneous in its composition so that it is possible that minor amounts of nondetrital smectite may be present and could have formed from the submarine alteration of small amounts of volcanic material. As we discuss below, this alteration would remove $\mathrm{Mg}$ and add $\mathrm{Ca}$ to the sediment pore waters.

The strongest $\mathrm{Ca}$ addition and $\mathrm{Mg}$ removal occur in the pore waters of the sediments from below 400 meters

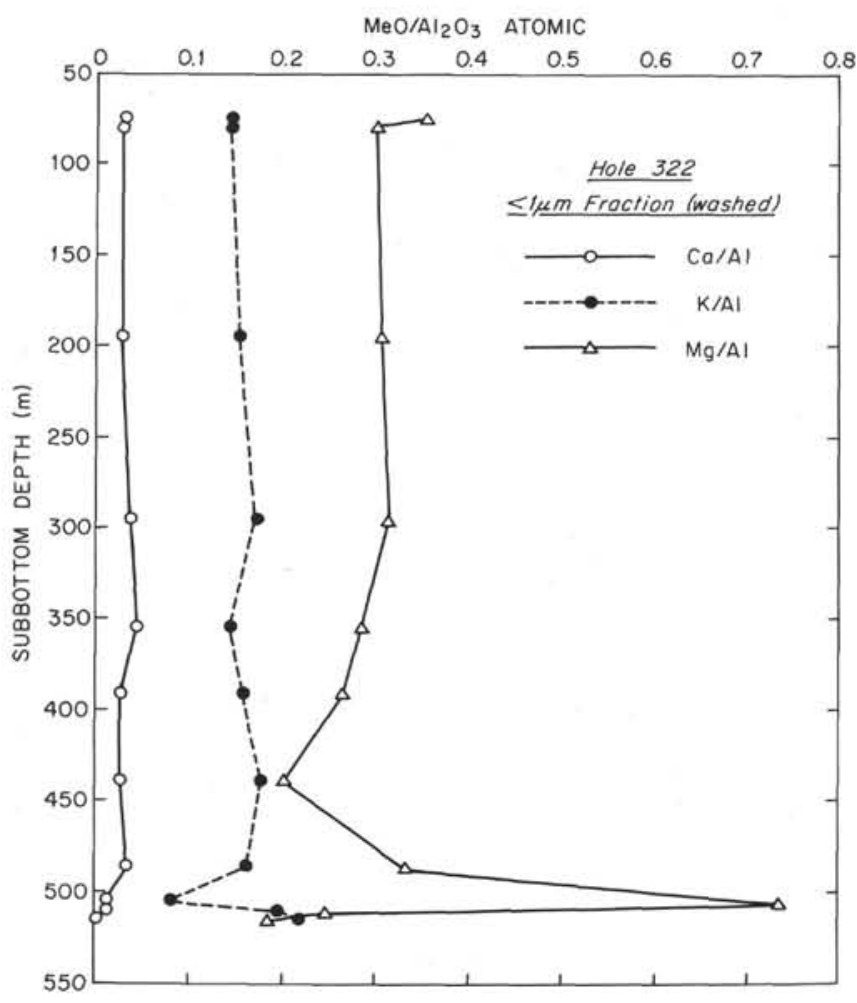

Figure 3. Atomic cation/Al ratios versus sample subbottom depth for the washed $<1 \mu \mathrm{m}$ fraction of sediments from Site 322.

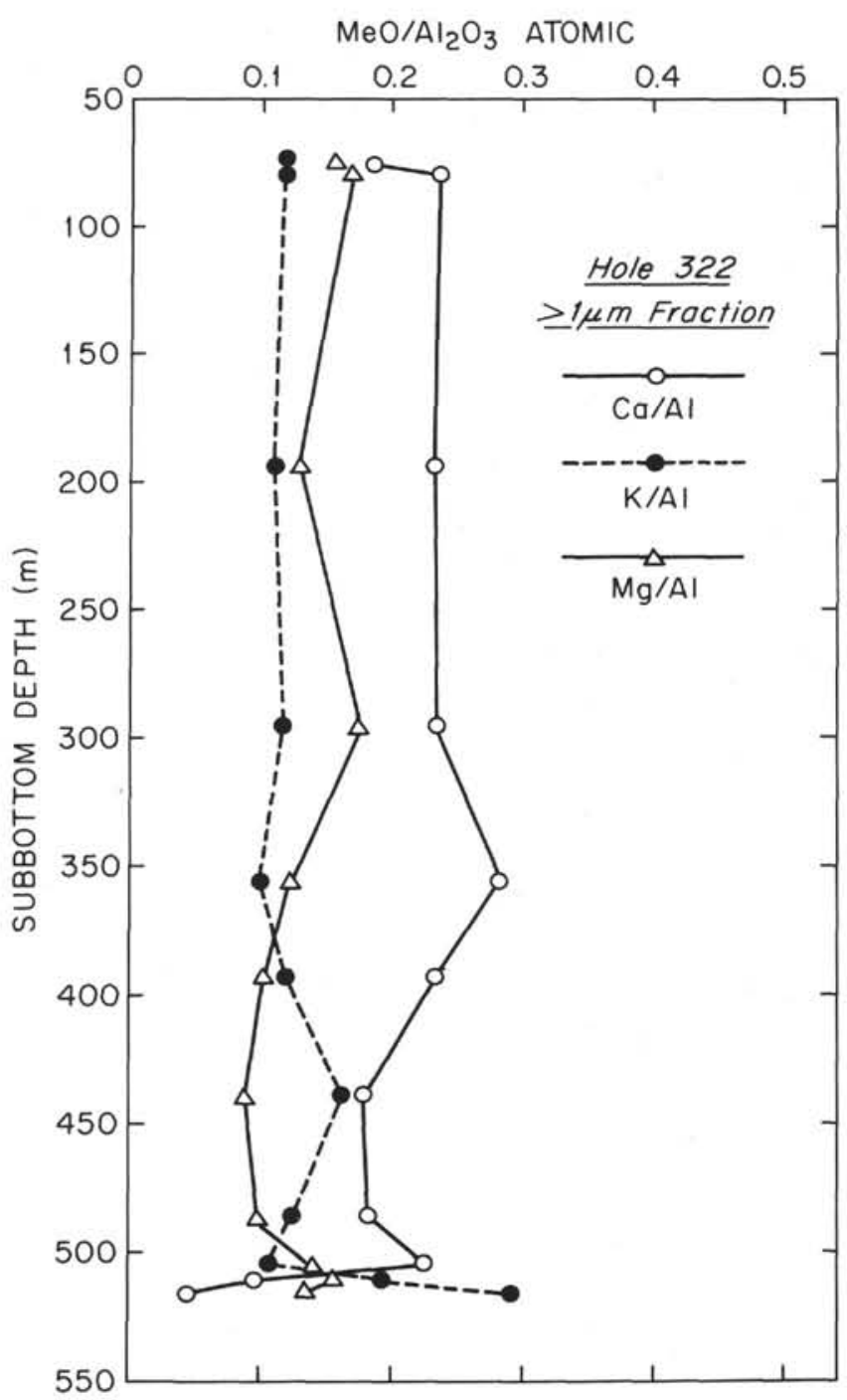

Figure 4. Atomic cation/Al ratios versus sample subbottom depth for the washed $>1 \mu \mathrm{m}$ fraction of sediments from Site 322.

(Gieskes and Lawrence, this volume). The sediments below this depth change in their clay mineralogy from a detrital suite to one dominated by authigenic smectite (Figure 1) which has formed as an alteration or submarine "weathering" product of volcanics. The silicate fractions of these sediments (which are enriched in smectites) have higher $\mathrm{O}^{18}$ contents than the above detrital sediments (Lawrence et al., this volume). These isotopic data are best explained by the submarine weathering of volcanics to a smectite phase (Savin and Epstein, 1970; Lawrence et al., in press).

The smectite formation can also contribute to the pore water gradients through the following reaction scheme. Volcanics are weathered to release both $\mathrm{Ca}$ and $\mathrm{Mg}$ to the pore water. The formation of smectite as a weathering product then removes not only the $\mathrm{Mg}$ released by the weathered volcanics but also the $\mathrm{Mg}$ initially present in the pore water itself. The smectite formation would also leave the pore waters depleted in $\mathrm{O}^{18}$, and the pore water gradient exhibits $\mathrm{O}^{18}$ depletion which 
is strongest in these deeper sediments. The alteration of the basal basalt underlying the sediments appears to affect the pore water gradients in a similar fashion and is also producing smectite as an alteration product.

The chemistry of the sediments does not strongly support the above hypothesis as it has done in earlier studies (Perry et al., in press). Both the coarse and the fine fractions of the deeper sediments exhibit a depletion in $\mathrm{Ca}$ (Figures 3 and 4), as do the altered basalts at the bottom of Hole 322 (Donnelly and Wallace, this volume; Drever, this volume). The $\mathrm{Mg}$ shows a general increase in the clay fraction (Figure 3) which correlates roughly with the smectite abundance, but the correlation is not as striking as it was for Site 149 sediments. At Site 149 the $\mathrm{Mg}$ uptake by authigenic smectite was very clearly demonstrated, but these were tropical sediments from the Venezuela Basin with no chlorite present and smectite was the only clay phase having an appreciable $\mathrm{Mg}$ content (Perry et al., in press). At Site 322 we have two $\mathrm{Mg}$ clay phases, smectite and detrital chlorite, so that the $\mathrm{Mg}$ content of the sediments can be controlled by detrital and/or authigenic phases. The detrital sediments at Site 322 have a much higher $\mathrm{Mg} / \mathrm{Al}$ ratio than the detrital sediments at Site 149. The pattern of $\mathrm{Mg}$ enrichment in the volcanic sediments is therefore not as clearly delineated from the detrital sediments. The volcanic sediments still exhibit some higher $\mathrm{Mg}$ contents than the terrigenous sediments, including the two data points in the basal 2 meters (Figure 3) which are also enriched in detrital components.

The pore waters also exhibit a slight depletion in $\mathrm{K}$, which may be reflected in the chemistry of the coarse fraction of the sediments (Figure 4). Clinoptilolite and phillipsite were observed in the deeper sediments and basal basalts. These zeolites appear to be the most likely sink for the pore water potassium, and they are more abundant in the coarse fraction of the sediments.

Hole 325 pore waters exhibit chemical and isotopic trends which are similar to those of Hole 322, but which are of an even larger magnitude (Gieskes and Lawrence, this volume; Lawrence et al., this volume). Basalt basement was not reached in this hole, but sediments enriched in authigenic smectite were again encountered at the bottom of the hole (Figure 2). Apparently the same reaction mechanisms discussed above for Hole 322 are operative at Site 325 . The deeper sediments, which presumably formed much closer to a ridge crest spreading center, are enriched in a volcanic component which is altering to smectite plus zeolite phases. Again, the alteration of the basement basalts may be proceeding in a similar fashion and also contributing to the chemical gradients observed in the pore waters.

\section{SUMMARY}

Site 322 has an upper 400-meter section of sediments which is dominantly of a terrigenous origin. Except for the basal 2 meters of sediments which are also enriched in detrital components, the deeper sediments have a clay mineralogy which is dominated by a smectite and lesser amounts of clinoptilolite. These minerals have formed from the submarine weathering of volcanics which causes a net $\mathrm{Mg}$ removal and a $\mathrm{Ca}$ addition to the pore waters. This weathering also causes the pore waters to become depleted in $\mathrm{O}^{18}$ and the smectites to become enriched in $\mathrm{O}^{18}$ relative to terrigenous illite/smectites. The pore water depletion in $\mathrm{K}$ is most probably caused by the formation of zeolites. The basal basalts weather by a mechanism similar to that of the volcanics in the overlying sediments.

Although the basalt basement was not reached at Site 325 , a similar, but more pronounced alteration of volcanics is indicated by the pore water chemical and isotopic data. The mineralogic data support this hypothesis in that the upper 630 meters of sediments are detrital in origin, but smectites are abundant in the deeper sediments. The sediment section is therefore similar to Site 322 .

The sediment chemical data generally indicate a $\mathrm{Mg}$ enrichment in the altered volcanics. The Mg enrichment is not as clearly delineated as has been found elsewhere because the upper sediment sections are already relatively enriched in $\mathrm{Mg}$ due to abundant chlorite derived from an Antarctic provenance.

\section{ACKNOWLEDGMENTS}

This research was supported by NSF Grant 40051 and ACSPRF Grant 7237-AC2.

\section{REFERENCES}

Lawrence, J.R., Gieskes, J.M., and Broecker, W.S., in press. Oxygen isotope and cation composition of DSDP pore waters and the alteration of layer II basalts: Earth Planet. Sci. Lett.

Perry, E.A., Gieskes, J.M. and Lawrence, J.R., in press. Mg, $\mathrm{Ca}$ and $\mathrm{O}^{18} / \mathrm{O}^{16}$ exchange in the sediment-pore water system, Hole 149, DSDP: Geochim. Cosmochim. Acta.

Reynolds, R.C. and Hower, J., 1970. The nature of interlayering in mixed-layer illite/montmorillonites: Clays Clay Mineral., v. 18 , p. 25-36.

Savin, S.M. and Epstein, S., 1970. The oxygen and hydrogen isotope geochemistry of ocean sediments and shales: Geochim. Cosmochim. Acta, v. 34, p. 43-63.

Towe, K.M., 1974. Quantitative clay petrology: The trees but not the forest: Clays Clay Mineral., v. 22, p. 375-378. 